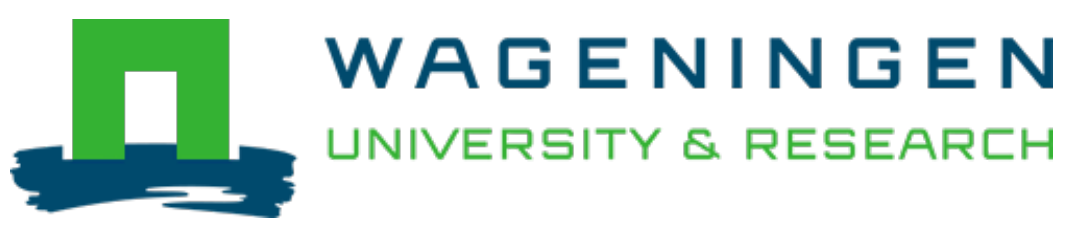

\title{
Consistency, polysaccharidase activities and non-starch polysaccharides content of soya beans during tempe fermentation.
}

\author{
Journal of the Science of Food and Agriculture \\ Reu, J.C.; Linssen, V.A.J.M.; Rombouts, F.M.; Nout, M.J.R. \\ https://doi.org/10.1002/(sici)1097-0010(199703)73:3<357::aid-jsfa738>3.0.c0;2-7
}

This publication is made publicly available in the institutional repository of Wageningen University and Research, under the terms of article $25 \mathrm{fa}$ of the Dutch Copyright Act, also known as the Amendment Taverne. This has been done with explicit consent by the author.

Article 25 fa states that the author of a short scientific work funded either wholly or partially by Dutch public funds is entitled to make that work publicly available for no consideration following a reasonable period of time after the work was first published, provided that clear reference is made to the source of the first publication of the work.

This publication is distributed under The Association of Universities in the Netherlands (VSNU) 'Article $25 \mathrm{fa}$ implementation' project. In this project research outputs of researchers employed by Dutch Universities that comply with the legal requirements of Article $25 \mathrm{fa}$ of the Dutch Copyright Act are distributed online and free of cost or other barriers in institutional repositories. Research outputs are distributed six months after their first online publication in the original published version and with proper attribution to the source of the original publication.

You are permitted to download and use the publication for personal purposes. All rights remain with the author(s) and / or copyright owner(s) of this work. Any use of the publication or parts of it other than authorised under article $25 \mathrm{fa}$ of the Dutch Copyright act is prohibited. Wageningen University \& Research and the author(s) of this publication shall not be held responsible or liable for any damages resulting from your (re)use of this publication.

For questions regarding the public availability of this publication please contact openscience.library@wur.nl 


\title{
Consistency, Polysaccharidase Activities and Non-Starch Polysaccharides Content of Soya Beans During Tempe Fermentation
}

\author{
Johan C de Reu, ${ }^{*}$ Viona A J M Linssen, Frank M Rombouts and M J Robert Nout
}

Wageningen Agricultural University, Department of Food Science, Bomenweg 2, 6703 HD Wageningen, The Netherlands

(Received 21 November 1994; revised version received 2 June 1995; accepted 17 September 1996)

\begin{abstract}
The relation between consistency of soya beans, polysaccharidase activities and the non-starch polysaccharides (NSP) content of soya beans was investigated during tempe fermentation. The fermentations were carried out in a rotating drum reactor (RDR) as well as in the traditional stationary tempe process. The firmness of the soya beans decreased rapidly during the first day of incubation. At increased incubation temperatures the hardness of the beans decreased more rapidly. In the RDR glycosidase activities became significantly higher beyond $48 \mathrm{~h}$ of incubation compared with the traditional process. This might have resulted from (a) the better control of temperature and gas composition in the RDR, and/or (b) the agitation in the RDR. The content of arabinose, galactose and uronic acids in the water-unextractable solids of NSP decreased more rapidly than that of glucose, mannose, xylose and fucose. These results indicate that during enzymatic maceration of soya beans in tempe fermentation, the arabinogalactan and pectin fractions are preferentially solubilised.
\end{abstract}

Key words: tempe, consistency, Rhizopus oligosporus, polysaccharidases, nonstarch polysaccharides, solid-substrate fermentation.

\section{INTRODUCTION}

Tempe is a traditional Indonesian fermented food which consists of cooked, dehulled soya beans, or other materials, bound into a solid cake by the growth of a mould, most commonly Rhizopus oligosporus (Nout and Rombouts 1990). In good-quality tempe the bean cotyledons are bound together sufficiently tightly to allow the product to be diced or sliced before frying.

Blakeman et al (1988) compared three methods for assessing fungal biomass in tempe. They found that the force required to draw a pin through tempe gave a good indication of the degree of mycelial growth and substrate binding and suggested that this was a more useful measure than direct determinations of fungal biomass

* To whom correspondence should be addressed. after enzymic digestion of the substrate or than assaying for $\mathrm{N}$-acetyl glucosamine.

Nout et al (1985) stated that uncooked tempe should have a consistency corresponding to a force of 1.5 $2.5 \mathrm{~N}$ required to break a cylinder of tempe $50 \mathrm{~mm}$ long and $15 \mathrm{~mm}$ in diameter suspended at its extremities. This procedure is only applicable to welldeveloped tempe and cannot be used to distinguish hyphal growth from the changes in consistency of the soya beans.

Ariffin et al (1994) described a quantitative method for measuring the strength of the hyphae binding the cotyledons together in soya bean tempe. The force to failure and the work to failure both increased from zero values before hyphal development to maximum values after about $30 \mathrm{~h}$ of incubation and then declined as the tempe aged and the hyphae started to deteriorate. 
Unfortunately, the authors neglected, without experimental evidence, the influence of the consistency on their results.

Sarrette et al (1992) described the production and activity of polysaccharidases, notably polygalacturonase, cellulase and xylanase, by Rhizopus oligosporus during tempe fermentation. The maximum activity for all polysaccharidases tested occurred 20 $30 \mathrm{~h}$ after inoculation.

The edible dry matter portion of soya beans consists of protein $\left(380 \mathrm{~g} \mathrm{~kg}^{-1}\right)$, total lipids $\left(240 \mathrm{~g} \mathrm{~kg}^{-1}\right)$, carbohydrates $\left(310 \mathrm{~g} \mathrm{~kg}^{-1}\right)$, fibre $\left(30 \mathrm{~g} \mathrm{~kg}^{-1}\right)$ and ash (40 $\mathrm{g} \mathrm{kg}^{-1}$ ) (MacCarty and Matthews 1984). The carbohydrate components can be divided into monosaccharides (minor quantities), oligosaccharides (100-150 $\mathrm{g} \mathrm{kg}^{-1}$ dry matter) (DM) and polysaccharides (130-220 $\mathrm{g} \mathrm{kg}^{-1} \mathrm{DM}$ ) (Fennema 1976). Important components which are related to the consistency of the soya beans are the plant cell wall polysaccharides. The cell wall polysaccharides can be divided into waterextractable polysaccharides and water-unextractable polysaccharides.

Several studies have focused on the isolation and characterisation of cell wall polysaccharides from soya beans. Arabinose, galactose, glucose and galacturonic acid are the prevalent sugar residues, in addition to smaller amounts of fucose, rhamnose, xylose and mannose (Brillout et al 1988; Schols et al 1993).

In the present study we investigated the production and activities of polysaccharidases in relation to the consistency of tempe. The fermentations were carried out with Rhizopus oligosporus at 25,30 and $37^{\circ} \mathrm{C}$ in the traditional process. The results were compared with those obtained in a rotating drum reactor (RDR) which was described previously by De Reu et al (1993). In this laboratory-scale bioreactor, temperature control during solid-substrate fermentation can be achieved with discontinuous or continuous rotation and forced evaporation by aeration. As a result of the rotation a granular product is obtained, in contrast with the cake-like solid mass resulting from the traditional process.

\section{MATERIALS AND METHODS}

\section{Organism}

Rhizopus microsporus var oligosporus strain LU 575 (NRRL 5905) was grown and maintained at $30^{\circ} \mathrm{C}$ on Malt Extract Agar (Oxoid, CM 59, UK). Sporangiospore suspensions were obtained by scraping off the sporangia from a culture after 7 days incubation at $30^{\circ} \mathrm{C}$, and suspending them in sterile distilled water containing Tween 80 ( $\left.1 \mathrm{ml} \mathrm{litre}{ }^{-1}\right)$ (Merck, Germany). The viable count varied between $5 \times 10^{5}$ and $10^{6} \mathrm{cfu} \mathrm{ml}^{-1}$, when determined on Rose-Bengal Chloramphenicol
Agar (Oxoid CM549). The sporangiospore suspensions were used immediately after preparation.

\section{Tempe manufacturing process}

Dehulled yellow-seeded soya beans (Glycine max L) were soaked overnight using the accelerated acidification method (Nout et al 1987). Subsequently, the beans ( $\mathrm{pH}$ soak water $<4 \cdot 2$ ) were washed with tap water and boiled for $20 \mathrm{~min}$, cooled, superficially dried (15$30 \mathrm{~min}$, at room temperature) and inoculated with sporangiospore suspension $\left(10 \mathrm{ml} \mathrm{kg}^{-1}\right)$.

Petri dishes $(\phi 9 \mathrm{~cm} ; 6$ side perforations, $\phi 1 \mathrm{~mm})$ were filled with $60 \mathrm{~g}$ inoculated beans, sealed with tape and incubated at 25,30 or $37^{\circ} \mathrm{C}$. An autoclaved RDR (De Reu et al 1993) was filled with $1 \mathrm{~kg}$ of cooked and inoculated soya beans. The reactor was placed in a temperature-controlled incubator at $30^{\circ} \mathrm{C}$. During the experiments a discontinuous rotating scheme was used to avoid substrate temperatures rising beyond $36^{\circ} \mathrm{C}$. After the substrate temperature reached $36^{\circ} \mathrm{C}$, the reactor vessel was rotated alternately clockwise $(6 \mathrm{~s}$ at $8 \mathrm{rpm})$ and counter-clockwise (6 s at $8 \mathrm{rpm})$ for $1 \mathrm{~min}$. Due to the rotation, the temperature of the substrate dropped by $1 \cdot 5-2 \cdot 0^{\circ} \mathrm{C}$. After rotation the reactor vessel was kept stationary until the substrate temperature reached $36^{\circ} \mathrm{C}$ again. Then the rotation cycle was repeated. This procedure resulted in a saw-tooth temperature pattern (De Reu et al 1993).

Samples for biochemical analysis were taken at various time intervals and immediately frozen in liquid nitrogen. The samples were stored at $-20^{\circ} \mathrm{C}$, lyophilised and stored at $-20^{\circ} \mathrm{C}$ in the dark until analysis. Although incubation is stopped after $30-48 \mathrm{~h}$ under production conditions, we continued the fermentation in the static samples for up to $144 \mathrm{~h}$ to observe the effects of on-going biochemical processes. After $72 \mathrm{~h}$ of incubation the material inside the RDR was removed and stored at $37^{\circ} \mathrm{C}$.

\section{Consistency}

To determine the consistency of the soya beans, 10-15 cotyledons were dissected carefully from the fermenting cake and placed in a Mulder device (Mulder 1946). With this system the force required to decrease the height of the individual cotyledons by $50 \%$ was determined. The Student's $t$-test (Owen 1962) was used to determine whether differences were significant.

\section{Enzyme extraction}

The tempe samples were ground and frozen in liquid nitrogen, and stored at $-80^{\circ} \mathrm{C}$ until analysis. Enzymes were extracted by adding 9.5 or $9.0 \mathrm{ml}$ water to 0.5 or 
$1.0 \mathrm{~g}$ of tempe, respectively, depending on the determined enzyme level of a previous trial.

\section{Enzyme assays}

Activities of enzymes were assayed by determination of reducing sugars released by the hydrolysis of polygalacturonic acid (Cat no 102711, ICN Pharmaceuticals, USA) for polygalacturonase activity; linear araban (NOVO, Denmark) for arabinase activity; birch xylan (Roth GmbH \& Co, Germany) for xylanase activity and carboxymethylcellulose (Akucell AF0305, AKZO, The Netherlands) for endocellulase activity. A mixture of $250 \mu \mathrm{l}$, containing $50 \mu \mathrm{l}$ substrate $\left(5 \mathrm{~g}\right.$ litre $^{-1}$ in water), $25 \mu$ l test sample and $175 \mu 150 \mathrm{~mm}$ sodium acetate buffer, $\mathrm{pH} 5 \cdot 0$, was incubated for $1 \mathrm{~h}$ at $30^{\circ} \mathrm{C}$. The release of reducing sugars was determined by the Nelson Somogyi method (Spiro 1966) using a Beckman DU-64 spectrophotometer at $520 \mathrm{~nm}$ (Beckman Instruments, Fullerton, CA, USA).

Activities of $\alpha$-D-xylopyranosidase, $\beta$-D-xylopyranosidase, $\alpha$-D-glucopyranosidase, $\beta$-D-glucopyranosidase, $\alpha$-D-galactopyranosidase, $\beta$-D-galactopyranosidase, $\alpha$-Dmannopyranosidase (Koch-Light, Colnbrook, Bucks, UK; Cat nos 14308, 14303, 14279, 14280, 14301, 14277 and 14285 , respectively), $\alpha$-L-arabinopyranosidase and $\alpha$-L-arabinofuranosidase (Sigma, USA, Cat nos N3512 and N3641, respectively) were measured using their corresponding $p$-nitrophenyl (PNP) derivatives as substrates. An aliquot of $100 \mu$ l test sample was added to $25 \mu \mathrm{l} \mathrm{PNP}$-substrate $\left(1 \mathrm{~g}\right.$ litre ${ }^{-1}$ in $50 \mathrm{~mm}$ sodium acetate buffer, $\mathrm{pH} 5.0$ ) and incubated for $1 \mathrm{~h}$ at $30^{\circ} \mathrm{C}$. The reaction was stopped by adding $125 \mu \mathrm{l}$ of $50 \mathrm{~mm}$ glycine buffer, $\mathrm{pH} 9.0$ with 2 mM EDTA. The released PNP was measured at $405 \mathrm{~nm}$, and quantified using a molar absorption coefficient of 13700 .

All activities were expressed in international units (U; $\left.\mu \mathrm{mol} \min ^{-1}\right)$. Measurements of enzyme activities were carried out in duplicate.

\section{Non-starch polysaccharides}

The total non-starch polysaccharides (NSP) content of the water-unextractable solids (WUS) fraction was estimated by adding the uronic acids content and the neutral sugar content.

\section{Uronic acid content}

The anhydro-uronic acid content of the WUS fraction was determined by the automated meta-hydroxydiphenyl assay (Thibault 1979).

\section{Neutral sugars}

Neutral sugars in the WUS fraction of tempe were analysed as non-starch polysaccharides (Englyst and Cummings 1984) using inositol as internal standard and pretreatment with $\mathrm{H}_{2} \mathrm{SO}_{4}\left(720 \mathrm{~g} \mathrm{~kg}^{-1}\right)$ for $1 \mathrm{~h}$ at $30^{\circ} \mathrm{C}$ prior to hydrolysis with $1 \mathrm{M}_{2} \mathrm{SO}_{4}$ for $3 \mathrm{~h}$ at $100^{\circ} \mathrm{C}$.

After starch hydrolysis, extraction and washing of the lyophilised tempe, according to Englyst and Cummings (1984) and Englyst et al (1992), WUS was obtained. The WUS fraction was hydrolysed. Alditol acetates were obtained after reduction and acetylation according to the method described by Englyst and Cummings (1984). Alditol acetates were separated using a DB1701 column $(30 \mathrm{~m}, 0.32 \mathrm{~mm} \phi)$ in a Carlo Erba GC (Carlo Erba Strumentazione, Rodano, Milan, Italy; type HRGC 5160) operated equipped with a flame ionisation detector.

Chromatography conditions were as follows: sample size, $1 \mu \mathrm{l}$; carrier gas, helium; pressure, $100 \mathrm{kPa}$; the temperature was programmed from 80 to $180^{\circ} \mathrm{C}$ at a rate of $2^{\circ} \mathrm{C} \mathrm{min}{ }^{-1}$ and from 180 to $270^{\circ} \mathrm{C}$ at a rate of $1.5^{\circ} \mathrm{C} \min ^{-1}$ and was kept for $3 \mathrm{~min}$ at $270^{\circ} \mathrm{C}$.

\section{RESULTS}

\section{Consistency}

In Fig 1 the effects of incubation temperatures and the incubation period on the consistency of soya beans are shown. After soaking, a force of $28.9 \pm 5.0 \mathrm{~N}$ was required to reduce the height of the cotyledons by 45 $50 \%$; subsequent cooking reduced the required force to $25.5 \pm 4.9 \mathrm{~N}$. During the first day of incubation the required force decreased rapidly from $25 \cdot 5 \pm 4.9 \mathrm{~N}$ to $13.6 \pm 4.6 \mathrm{~N}, \quad 11.0 \pm 4.6 \mathrm{~N}, \quad 10 \cdot 1 \pm 3.2 \mathrm{~N}$ and $7 \cdot 3 \pm 1.4 \mathrm{~N}$ at $25,30,37^{\circ} \mathrm{C}$ and in the RDR $\left(36^{\circ} \mathrm{C}\right)$, respectively. During further incubation this order was maintained. The decrease in the required forces was less marked after the first day.

The firmness of the RDR-fermented material was significantly less $(P<0 \cdot 05)$ than that of the traditionally fermented product, except after $48 \mathrm{~h}$ of incubation. Between 25 and $30^{\circ} \mathrm{C}$, no significant differences $(P>0 \cdot 05)$ were observed after 1,2 and 3 days of incubation. The consistency of the beans fermented at $30^{\circ} \mathrm{C}$ and $37^{\circ} \mathrm{C}$ became significantly different $(P<0.05)$ beyond $72 \mathrm{~h}$ of incubation.

\section{Enzyme activity}

In Table 1 the enzyme activities during the fermentation of soya beans with $R$ oligosporus are shown for the traditional fermentation at 25,30 or $37^{\circ} \mathrm{C}$ and for the agitated process in the RDR. The total enzyme activities (TEA) in the RDR and at $37^{\circ} \mathrm{C}$ were similar after $48 \mathrm{~h}$ 


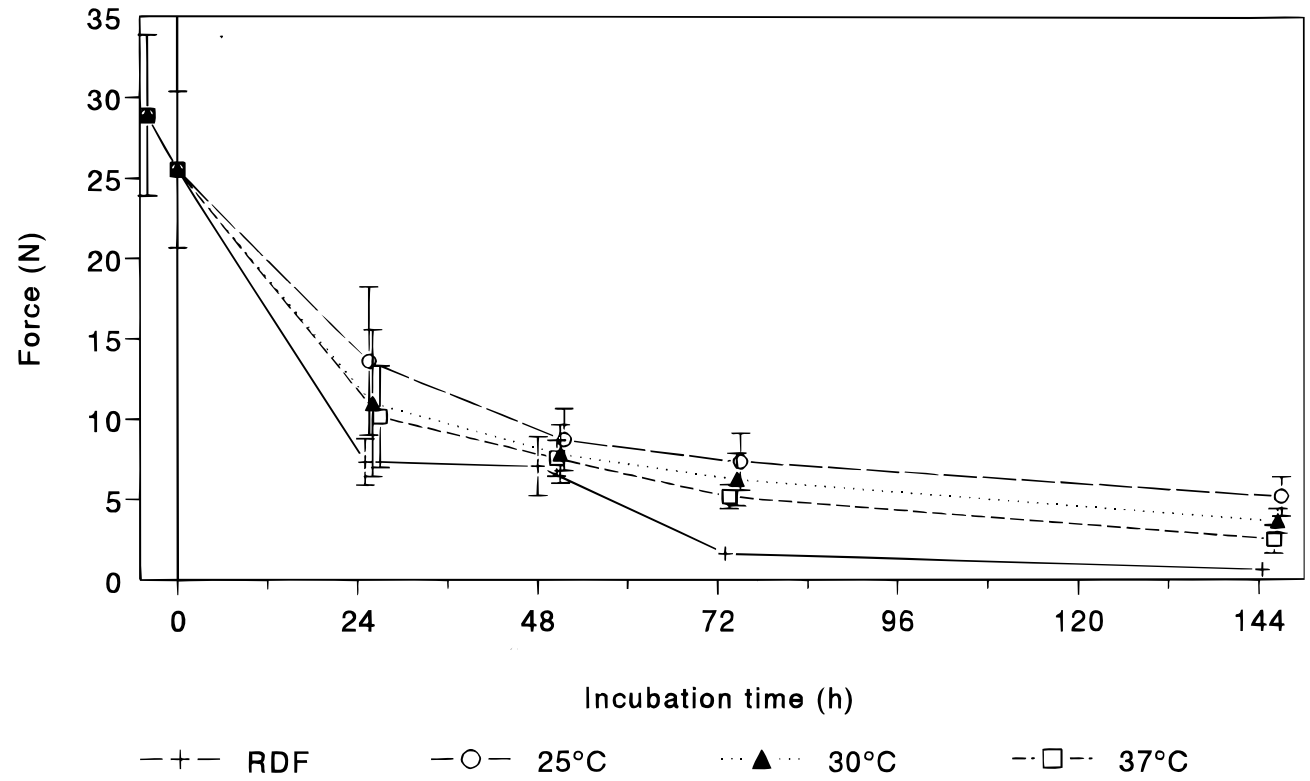

Fig 1. The consistency of tempe as a function of the incubation time. Fermentations took place in the traditional system at 25,30 and $37^{\circ} \mathrm{C}$ and in the rotating drum reactor at $36^{\circ} \mathrm{C}$. The results on the $y$-axis represent means and standard deviation $(n=10-15)$. $T=-4 \mathrm{~h}$ represents soaked beans. $T=0 \mathrm{~h}$ represents cooked soya beans after inoculation.

of incubation. During the third day of incubation the TEA increased in the RDR, whereas the TEA at $37^{\circ} \mathrm{C}$ decreased.

If the TEA is divided into enzyme activity on polymers and that on glycosides some interesting differences are observed. In the traditional non-agitated fermenta- tions the ratio depolymerases: glycosidases increased rapidly up to $72 \mathrm{~h}$ of incubation. In other words, in this system activity on polysaccharides was more important than glycosidase activity. If the incubation temperatures were compared, a significant increase in TEA was observed at $37^{\circ} \mathrm{C}$ compared with 25 or $30^{\circ} \mathrm{C}$. When the

TABLE 1

Enzyme activities $\left(\mathrm{U} \mathrm{g}^{-1}\right.$ lyophilised tempe) during the fermentation of soya beans in the stationary traditional process at 25,30 and $37^{\circ} \mathrm{C}$ and in an agitated rotating drum reactor $(\mathrm{RDR})$ at $36^{\circ} \mathrm{C}$

\begin{tabular}{|c|c|c|c|c|c|c|c|c|c|c|c|c|c|}
\hline & \multicolumn{4}{|c|}{$R D R\left(36^{\circ} C\right)$} & \multicolumn{3}{|c|}{$25^{\circ} \mathrm{C}$} & \multicolumn{3}{|c|}{$30^{\circ} \mathrm{C}$} & \multicolumn{3}{|c|}{$37^{\circ} \mathrm{C}$} \\
\hline & $0 h$ & $24 h$ & $48 h$ & $72 h$ & $24 h$ & $48 h$ & $72 h$ & $24 h$ & $48 h$ & $72 h$ & $24 h$ & $48 h$ & $72 h$ \\
\hline \multicolumn{14}{|l|}{ Activity on polymers (I): } \\
\hline Arabinase & 1 & $-1^{a}$ & 5 & 0 & 1 & 2 & 6 & 0 & 1 & 2 & $-2^{a}$ & 10 & 10 \\
\hline Cellulase & 1 & 0 & 5 & 2 & 0 & 2 & 1 & 1 & 1 & 3 & 3 & 8 & 3 \\
\hline Polygalacturonase & 1 & 6 & 5 & 5 & 2 & 2 & 3 & 1 & 1 & 3 & 7 & 5 & 8 \\
\hline Xylanase & 1 & 3 & 4 & 3 & 1 & 1 & 1 & 1 & 1 & 3 & 5 & 7 & 6 \\
\hline Subtotal & 4 & 9 & 19 & 10 & 4 & 7 & 11 & 3 & 4 & 11 & 13 & 30 & 27 \\
\hline \multicolumn{14}{|l|}{ Glycosidase activities (II): } \\
\hline$\alpha$-Galactosidase & 1 & 4 & 5 & 11 & 3 & 2 & 2 & 2 & 4 & 2 & 5 & 4 & 3 \\
\hline$\beta$-Galactosidase & 1 & 4 & 4 & 7 & 3 & 2 & 2 & 1 & 3 & 2 & 4 & 3 & 2 \\
\hline$\alpha$-Xylosidase & 1 & 3 & 4 & 6 & 4 & 2 & 4 & 3 & 4 & 5 & 3 & 3 & 3 \\
\hline$\beta$-Xylosidase & 1 & 4 & 4 & 7 & 3 & 2 & 2 & 2 & 4 & 2 & 3 & 3 & 2 \\
\hline$\alpha$-Mannosidase & 1 & 2 & 4 & 7 & 3 & 3 & 2 & 1 & 3 & 2 & 3 & 3 & 2 \\
\hline$\alpha$-Glucosidase & 1 & 2 & 4 & 7 & 3 & 2 & 2 & 2 & 4 & 2 & 4 & 3 & 2 \\
\hline$\beta$-Glucosidase & 1 & 3 & 4 & 7 & 3 & 2 & 2 & 2 & 4 & 2 & 4 & 3 & 2 \\
\hline Arabinofuranosidase & 1 & 3 & 4 & 10 & 3 & 2 & 1 & 1 & 3 & 2 & 3 & 2 & 2 \\
\hline Arabinopyranosidase & 1 & 3 & 3 & 7 & 3 & 2 & 2 & 1 & 4 & 2 & 3 & 2 & 2 \\
\hline Subtotal & 9 & 28 & 36 & 69 & 28 & 19 & 19 & 15 & 33 & 21 & 32 & 26 & 20 \\
\hline Total & 13 & 37 & 55 & 79 & 32 & 26 & 30 & 18 & 37 & 32 & 45 & 56 & 47 \\
\hline Ratio (I)/(II) & $0 \cdot 21$ & $0 \cdot 29$ & $0 \cdot 51$ & $0 \cdot 16$ & $0 \cdot 12$ & $0 \cdot 31$ & 0.73 & $0 \cdot 19$ & $0 \cdot 17$ & 0.59 & $0 \cdot 44$ & $1 \cdot 17$ & $1 \cdot 47$ \\
\hline
\end{tabular}

${ }^{a}$ Negative values were obtained due to correction for blank results. 
individual depolymerases or glycosidases were compared, only small differences could be detected.

\section{Non-starch polysaccharides}

In Table 2 the neutral sugars and uronic acid contents of soya beans are shown for the fermentation with $R$ oligosporus at 25,30 or $37^{\circ} \mathrm{C}$ in the traditional stationary system, as well as in the agitated RDR. During incubation a drop in total NSP was observed. The higher the incubation temperature the lower the level of
NSP in the WUS fraction at the end of the incubation. The differences in NSP content between the RDR and the traditional system at $37^{\circ} \mathrm{C}$ were very small.

\section{Consistency vs enzyme activities and NSP content}

In Fig 2 the relation between total polysaccharidase activities and the force $(\mathrm{N})$ required to give a reduction of $50 \%$ in height of the cotyledons is shown. The higher the enzyme activity the less was the force required for this reduction. Compared to the firmness of cooked inoculated beans a significant decrease of the force

TABLE 2

Non-starch polysaccharides content ( $\mu \mathrm{mol} \mathrm{g}^{-1}$ water-unextractable solids) during the fermentation of soya beans in the stationary traditional process at 25,30 and $37^{\circ} \mathrm{C}$ and in an agitated rotating drum reactor (RDR) at $36^{\circ} \mathrm{C}$

\begin{tabular}{|c|c|c|c|c|c|c|c|c|c|c|c|c|c|}
\hline & \multicolumn{4}{|c|}{$R D R\left(36^{\circ} C\right)$} & \multicolumn{3}{|c|}{$25^{\circ} \mathrm{C}$} & \multicolumn{3}{|c|}{$30^{\circ} \mathrm{C}$} & \multicolumn{3}{|c|}{$37^{\circ} \mathrm{C}$} \\
\hline & $0 h$ & $24 h$ & $48 h$ & $72 h$ & $24 h$ & $48 h$ & $72 h$ & $24 h$ & $48 h$ & $72 h$ & $24 h$ & $48 h$ & $72 h$ \\
\hline Arabinose & 339 & 263 & 187 & 194 & 383 & 243 & 263 & 284 & 262 & 220 & 319 & 195 & 163 \\
\hline Fucose & 48 & 44 & 35 & 36 & 54 & 44 & 50 & 48 & 46 & 43 & 47 & 38 & 34 \\
\hline Galactose & 625 & 497 & 356 & 350 & 684 & 477 & 518 & 548 & 496 & 429 & 595 & 387 & 350 \\
\hline Glucose & 420 & 563 & 430 & 405 & 648 & 554 & 613 & 486 & 658 & 546 & 574 & 386 & 358 \\
\hline Mannose & 43 & 45 & 43 & 43 & 49 & 44 & 45 & 46 & 45 & 42 & 44 & 35 & 33 \\
\hline Rhamnose & 32 & 26 & 18 & 19 & 36 & 24 & 27 & 30 & 25 & 22 & 29 & 20 & 16 \\
\hline Xylose & 139 & 134 & 94 & 96 & 171 & 123 & 129 & 127 & 140 & 114 & 145 & 91 & 81 \\
\hline Uronic acids & 72 & 16 & 16 & 10 & 57 & 54 & 57 & 69 & 52 & 54 & 46 & 39 & 27 \\
\hline Total: & 1718 & 1588 & 1179 & 1053 & 2082 & 1563 & 1702 & 1638 & 1724 & 1470 & 1799 & 1191 & 1062 \\
\hline
\end{tabular}

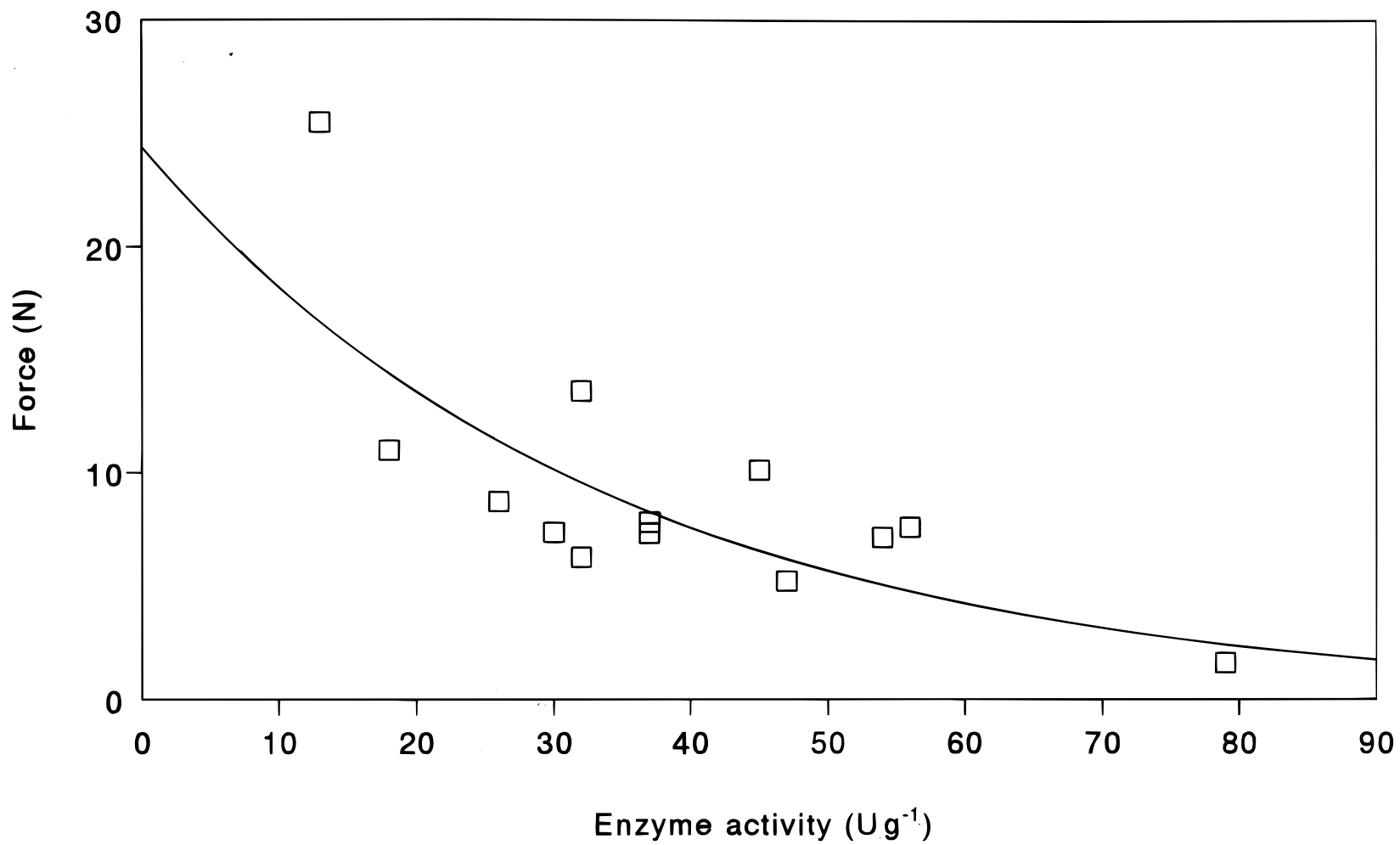

Fig 2. Relationship between total polysaccharidase activities $\left(\mathrm{U} \mathrm{g}^{-1}\right)$ and the force $(\mathrm{N})$ required to give a reduction of $50 \%$ in height of the soya cotyledons. Results represent pooled data of experiments carried out in the RDR and the traditional fermentation system. $(\square)$ Fermented samples. 
required resulted from very low enzyme activities. A maximum $r^{2}$ value of 0.77 was obtained when the data were fitted to an exponential curve.

In Fig 3 the relation between the NSP-content $\left(\mu \mathrm{mol} \mathrm{g}{ }^{-1}\right.$ WUS) of the soya beans and the force (N) required to obtain a $50 \%$ reduction in height is shown. Increases above the initial value of $1718 \mu \mathrm{mol} \mathrm{NSP} \mathrm{g}^{-1}$ WUS might be due to shifts in the composition of the WUS fraction, eg protein becomes more soluble during fermentation (De Reu 1995). The lower the NSP content, the less was the force required, indicating a less firm structure.

\section{DISCUSSION}

In tempe research little attention has been paid to polysaccharidases and their effects on the consistency of soya beans. It is expected that during fermentation the hyphae may soften the soya beans by enzymatic degradation of cell walls and mechanically pushing the cells apart. This expectation is supported by histological observations of growth of $R$ oligosporus on soya beans by Jurus and Sundberg (1976). Penetration and growth of the hyphae were generally inwardly directed and perpendicular to the surface of the cells. The degree of distortion caused by the fungus was most severe at or near the cotyledon surface. Portions of the outermost cell layers of the cotyledon were often completely permeated with mycelium, creating an indistinct mass. The walls of these cells were shrivelled, the cytoplasm was very distorted, and frequently tissue was so grossly disrupted that individual cells were no longer recognisable. Fewer hyphae and little or no distortion were observed among the inner cellular layers of the cotyledon (Jurus and Sundberg 1976). After penetration of the outer layers of the cotyledons, the energy sources in the inner tissue, eg lipids (De Reu et al 1994) and proteins become accessible to hydrolysis by lipases and proteases, respectively.

The major reduction in consistency was observed during the first day of incubation, which implies that during the initial growth stages of fungal development mechanical and enzymatic maceration are very effective. It seems that cell wall polysaccharides which are involved in maintaining the structural integrity of the beans could be hydrolysed easily during the first $24 \mathrm{~h}$ of incubation. After $24 \mathrm{~h}$ some specific parts of the remaining structure were solubilised, without decreasing the consistency a lot. Those specific parts consist of arabinose, galactose and uronic acids as shown in Table 2. This indicates that the arabinogalactan and pectin fractions were preferentially solubilised.

As described earlier (De Reu et al 1993), the RDR enables solid-substrate fermentations to be conducted under controlled conditions of temperature and oxygen supply by avoiding heat and mass transfer limitation problems. As expected, growth-limiting conditions were

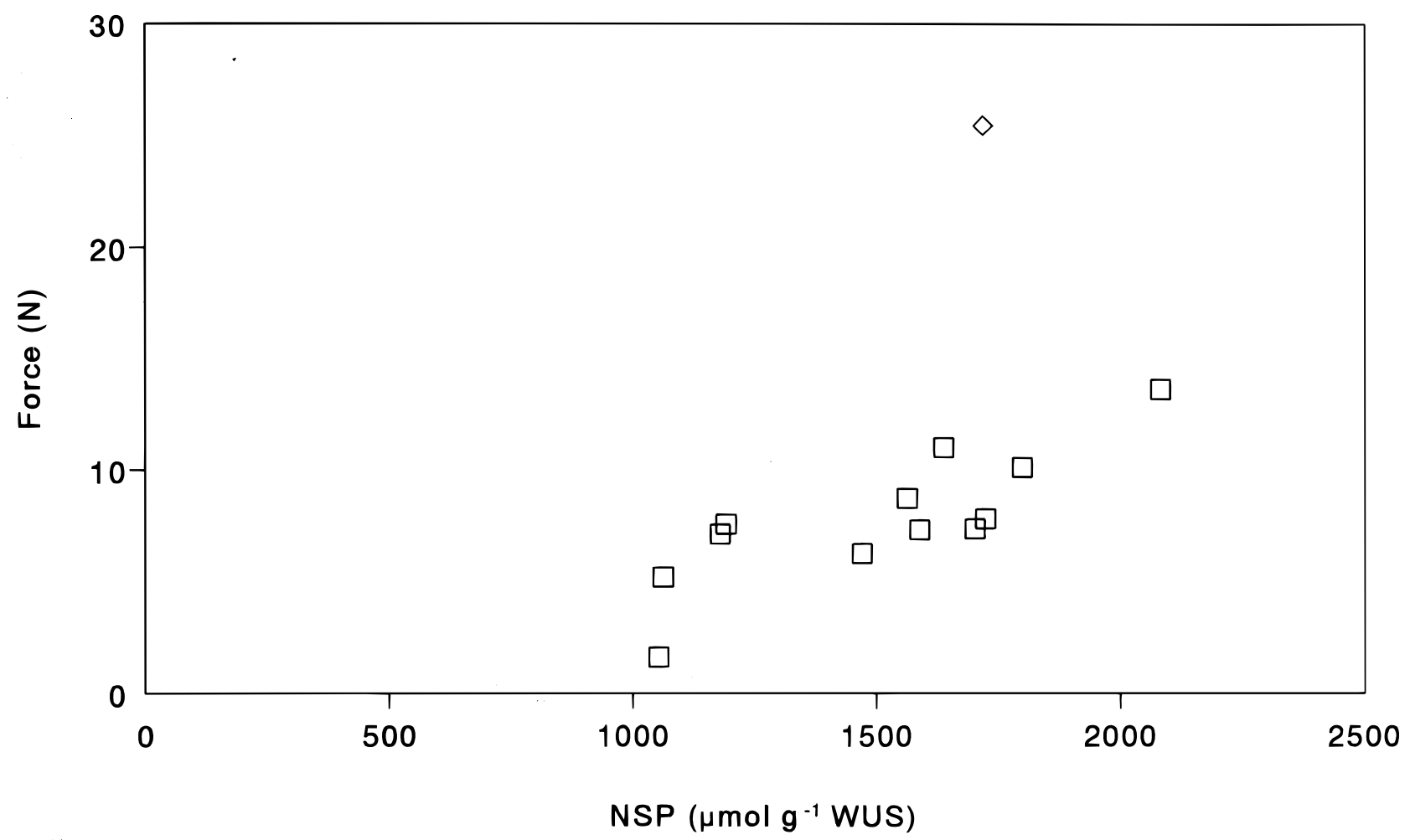

Fig 3. Relationship between non-starch polysaccharides content of soya beans ( $\mu \mathrm{mol}^{-1}$ water-unextractable solids) and the force (N) required to give a reduction of $50 \%$ in height of the soya cotyledons. Results represent pooled data of the experiments carried out in the RDR and the traditional fermentation system. $(\diamond)$ Cooked inoculated beans, and $(\square)$ fermented samples. 
rapidly reached in the traditional packed-bed systems. After $48 \mathrm{~h}$ of incubation the total enzyme activity increased rapidly in the RDR while in the traditional systems maximum enzyme activity had already been passed.

In the RDR consistency changed as a function of both enzyme activity and shear forces during agitation, and therefore it is not surprising that the hardness was less than in the product of stationary fermentation. However, we were not able to distinguish whether this was due to the higher total enzyme activity or to the effect of shear forces or a combination of both.

The reduction of arabinose, galactose and uronic acids (Table 2) shows that during enzymatic maceration arabinogalactan and pectin were the predominant fractions solubilised. During tempe fermentation, growth of $R$ oligosporus on soya beans resulted in complex biochemical and physical changes in the beans. The results might be used to form a link between previous histological observations and cell wall structure studies. The observed changes improve the fundamental knowledge about the tempe process and could be used to optimise the production process, in particular in determining the required incubation time.

\section{ACKNOWLEDGEMENT}

The authors gratefully acknowledge the financial support of Nutricia Research, Zoetermeer, The Netherlands.

\section{REFERENCES}

Ariffin R, Apostolopoulos C, Graffham A, MacDougall D, Owens J D 1994 Assessment of hyphal binding in tempe. Lett Appl Microbiol 18 32-34.

Blakeman J P, McCracken A R, Seaby D A 1988 Changes brought about in solid substrates after fermentation of mixtures of cereals and pulses with Rhizopus oryzae. J Sci Food Agric 45 109-118.

Brillout J M, Rouau X, Hoebler C, Barry J L, Carre B, Lorta E 1988 A new method for determination of insoluble cell walls and soluble non-starchy polysaccharides from plant materials. J Agric Food Chem 36 969-979.
De Reu J C 1995 Solid-Substrate Fermentation of Soya Beans to Tempe, Process Innovations and Product Characteristics. $\mathrm{PhD}$ thesis, Wageningen Agricultural University, The Netherlands.

De Reu J C, Zwietering M H, Rombouts F M, Nout M J R 1993 Temperature control in solid substrate fermentation through discontinuous rotation. Appl Microbiol Biotechnol 40 261-265.

De Reu J C, Ramdaras D, Rombouts F M, Nout M J R 1994 Changes in soya bean lipids during tempe fermentation. Food Chem 50 171-175.

Englyst H N, Cummings J H 1984 Simplified method for the measurement of total non-starch polysaccharides by GLC of constituent sugars as alditol acetates. Analyst 109937 942.

Englyst H N, Quigly M E, Hudson G J, Cummings J H 1992 Determination of dietary fibre as non-starch polysaccharides by gas-liquid chromatography. Analyst 117 $1707-1714$.

Fennema O R 1976 Principles of Food Science, part I: Food Chemistry. Marcel Dekker Inc, New York, USA.

Jurus A M, Sundberg W J 1976 Penetration of Rhizopus oligosporus into soybeans in tempeh. Appl Environ Microbiol 32 284-287.

MacCarty M A, Matthews R H 1984 Composition of Foods: Nut and Seed Products: Raw, Processed, Prepared. USDA, Washington, DC, USA.

Mulder H 1946 Het bepalen van reologische eigenschappen van kaas. Verslag Landbouwkd Onderz 51 467-487.

Nout M J R, Rombouts F M 1990 Recent developments in tempe research. J Appl Bacteriol $69609-633$.

Nout M J R, Bonants-Van Laarhoven T M G, De Dreu R 1985 The influence of some process and storage conditions on the quality and shelf life of soybean tempeh. Antonie Leeuwenhoek 51 532-534.

Nout M J R, De Dreu R, Zuurbier A M, Bonants-Van Laarhoven T M G 1987 Ecology of controlled soya bean acidification for tempe manufacture. Food Microbiol 4 165-172.

Owen D B 1962 Handbook of Statistical Tables. Addison Wesley Publishing, Inc, Reading, Massachusetts, USA.

Sarrette M, Nout M J R, Gervais P, Rombouts F M 1992 Effect of water activity on production and activity of Rhizopus oligosporus polysaccharidases. Appl Microbiol Biotechnol 37 420-425.

Schols H A, Lucas-Lokhorst G, Voragen A G J, Niessen W M A 1993 Isolation and characterization of cell wall polysaccharides from soya bean. Carbohydr Neth 9 7-10.

Spiro R G 1966 Analysis of sugars found in glycoproteins. Meth Enzymol 8 3-26.

Thibault J-F 1979 Automatisation du dosage des substances pectiques par la méthode au méta-hydroxydiphenyl. Lebensm Wiss Technol 12 247-251. 